\title{
Chemical Compounds Effective Against the Citrus Huanglongbing Bacterium 'Candidatus Liberibacter asiaticus' In Planta
}

\author{
Muqing Zhang, Charles A. Powell, Lijuan Zhou, Zhenli He, Ed Stover, and Yongping Duan
}

First, second, third, and fourth authors: IFAS-IRREC, University of Florida, Fort Pierce 34945; and fifth and sixth authors: United States Department of Agriculture-Agricultural Research Service, USHRL, Fort Pierce, FL 34945.

Accepted for publication 13 March 2011.

\section{ABSTRACT}

Zhang, M. Q., Powell, C. A., Zhou, L. J., He, Z. L., Stover, E., and Duan, Y. P. 2011. Chemical compounds effective against the citrus Huanglongbing bacterium 'Candidatus Liberibacter asiaticus' in planta. Phytopathology 101:1097-1103.

Citrus Huanglongbing (HLB) is one of the most destructive diseases of citrus worldwide and is threatening the survival of the Floridian citrus industry. Currently, there is no established cure for this century-old and emerging disease. As a possible control strategy for citrus HLB, therapeutic compounds were screened using a propagation test system with 'Candidatus Liberibacter asiaticus'-infected periwinkle and citrus plants. The results demonstrated that the combination of penicillin and streptomycin (PS) was effective in eliminating or suppressing the ' $\mathrm{Ca}$. L. asiaticus' bacterium and provided a therapeutically effective level of control for a much longer period of time than when administering either antibiotic separately. When treated with the PS, 'Ca. L. asiaticus'infected periwinkle cuttings achieved $70 \%$ of regeneration rates versus $<50 \%$ by other treatments. The ' $\mathrm{Ca}$. L. asiaticus' bacterial titers in the infected periwinkle plants, as measured by quantitative real-time polymerase chain reaction, decreased significantly following root soaking or foliar spraying with PS. Application of the PS via trunk injection or root soaking also eliminated or suppressed the ' $\mathrm{Ca}$. L. asiaticus' bacterium in the HLB-affected citrus plants. This may provide a useful tool for the management of citrus HLB and other Liberibacter-associated diseases.

Additional keywords: 2,2-dibromo-3-nitrilopropionamide, oxytetracycline, penicillin $\mathrm{G}$ potassium.
Citrus Huanglongbing (HLB), also known as citrus greening, is the most economically devastating disease of citrus worldwide. All commercial citrus industries that have faced the disease suffer a decline in both production and profit (19). It has been estimated that nearly 100 million trees in 40 countries have been affected by HLB (16). In the 1960s, Reunion Island lost its entire citrus industry due to HLB (21,32). In Florida, citrus HLB, first detected in August 2005 (39), is now present in all commercial citrus-producing counties and is threatening the survival of the $\$ 9$ billion citrus industry. The HLB bacterium, 'Candidatus Liberibacter asiaticus' is a gram-negative, fastidious $\alpha$-proteobacterium. The bacterium propagates within the phloem of the host plants, resulting in die-back, yellow shoots, blotchy mottles on leaves, and off-tasting, malformed fruit (23). The disease spreads relatively fast in citrus groves where control measures (such as vector control) are not properly implemented, reaching more than $95 \%$ incidence in as little as 3 years after the first infection $(11,17)$. As the disease severity increases, the yield is significantly reduced and, thereby, the lifespan for the profitable productivity of citrus trees is dramatically shortened $(4,33)$.

To date, there are limited control practices for preventing further spread of HLB, and all known citrus species, cultivars, or combinations of scion and rootstock are susceptible to HLB $(2,5-$ 8). Control and management measures are currently limited to reducing inoculum sources by utilizing disease-free propagating

Corresponding author: Y. P. Duan; E-mail address: Yongping.duan@ars.usda.gov

* The $\boldsymbol{e}$-Xtra logo stands for "electronic extra" and indicates that the online version contains two supplemental figures. Figures 4 and 5 appear in color online.

doi:10.1094/PHYTO-09-10-0262

This article is in the public domain and not copyrightable. It may be freely reprinted with customary crediting of the source. The American Phytopathological Society, 2011 stock, removing symptomatic trees, and reducing transmission of the bacterium by control of the insect vectors (4).

Antibiotics have been used to control bacterial diseases of fruit trees and to limit the contamination of micropropagation and plant tissue cultures for $>50$ years $(31,42)$. Nearly 40 antibiotics have been screened for plant disease control but $<10$ have been used commercially and, of those, only streptomycin and tetracycline have had significant usage in fruit trees (31). Usage of streptomycin and tetracycline on plants accounted for $0.1 \%$ of all antibiotics produced annually in the United States in $1995(3,26)$. During the 1970s, tetracycline was evaluated by direct injection into the trunks of HLB-affected citrus trees in South Africa, China, and Indonesia $(38,40,41)$. This work noted a significant reduction of symptoms in treated trees $(14,35,37)$. However, this control practice was later discontinued because tetracycline is only bacteriostatic, not bactericidal, requiring treatment to be repeated each year. In addition, after several trunk injections, the phytotoxicity of the antibiotic became apparent in the injected citrus trees $(30,36)$. Development of a bactericide or other therapeutic compounds for the control of HLB would provide an additional solution for effective disease management. However, with the exception of selected antibiotics, there is no systemic bactericide that has been registered for general use on most crops and, specifically, citrus (25). Here, we present a new combination of antibiotics that can effectively eliminate or suppress the HLB bacterium both in ' $C a$. L. asiaticus'-infected periwinkle and HLB-affected citrus plants.

\section{MATERIALS AND METHODS}

HLB-affected citrus. Healthy 2-year-old grapefruit (Citrus paradisi) seedlings were graft inoculated with HLB-affected lemon (C. limon) scions in August 2008 and were subsequently maintained in the greenhouse. After 10 months, the typical HLB 
symptoms with vein corking and blotchy mottles appeared on the leaves of inoculated grapefruit seedlings. HLB-affected citrus seedlings with typical HLB symptoms were tested for the presence of ' $\mathrm{Ca}$. L. asiaticus' bacteria by using quantitative realtime polymerase chain reaction (qPCR) with ' $\mathrm{Ca}$. L. asiaticus'specific primers (HLBas, HLBr, and HLBp) (27). For field studies, HLB-affected citrus plants at the USHRL farm at Fort Pierce, FL were also analyzed using qPCR detection methods.

'Ca. L. asiaticus'-infected periwinkle. ' $C a$. L. asiaticus'-infected periwinkle (Catharanthus roseus) plants were propagated by graft transmission as described previously (43). Briefly, newly expanded branches of ' $\mathrm{Ca}$. L. asiaticus'-infected periwinkle were graft inoculated on ' $\mathrm{Ca}$. L. asiaticus'-free periwinkle plants. Transmission was confirmed via qPCR using ' $\mathrm{Ca}$. L. asiaticus'-specific primer sets (HLBas, HLBr, and HLBp) (27). All ' $\mathrm{Ca}$. L. asiaticus'-infected periwinkle plants were maintained in the greenhouse for further studies.

Antibiotic treatments using ' $\boldsymbol{C} \boldsymbol{a}$. L. asiaticus'-infected periwinkle. Comparison of three treatments. Three chemical treatments were evaluated for their potential to eliminate ' $\mathrm{Ca}$. L. asiaticus' bacterium infection: (i) antibiotic combination of penicillin $\mathrm{G}$ and streptomycin (PS) (penicillin G potassium salt at $100 \mu \mathrm{g} / \mathrm{ml}$ and streptomycin at $10 \mu \mathrm{g} / \mathrm{ml}$ ) (Sigma-Aldrich, St. Louis, MO), (ii) the antibiotic oxytetracycline (Oxy) $(100 \mu \mathrm{g} / \mathrm{ml})$ (Sigma-Aldrich), and (iii) biocide agent 2,2-dibromo-3-nitrilopropionamide (DBNPA) $(200 \mu \mathrm{l} /$ liter) (Dow Chemical, Midland, MI). The stems of ' $\mathrm{Ca}$. L. asiaticus'-infected cuttings were soaked individually in the above solutions for $4 \mathrm{~h}$ and then planted in $100 \%$ vermiculite using the optimized regeneration test system as described before (43). The cuttings were further treated with the same solutions at 7 and 14 days post transplanting by drenching the potting media with $10 \mathrm{ml}$ per cutting. Each experiment was repeated twice using 15 cuttings per treatment. After 2 months from the initial treatment, the numbers of plants regenerated from cuttings were recorded to determine the regeneration rate (percent). In the foliar-spraying experiment, thirty ' $\mathrm{Ca}$. L. asiaticus'infected periwinkle plants were divided into three groups and each group was foliar sprayed with one of three solutions (PS, Oxy, and DBNPA) with Silwet L-77 at $20 \mu \mathrm{l} / \mathrm{ml}$ using a ZEP $32-\mathrm{oz}$ professional sprayer a total of three times at 1 -week intervals. Each plant was sprayed to drip with $\approx 100 \mathrm{ml}$ of chemical solution.

Comparison of PS rates and adjuvants. The effects of PS application rates and inclusion of adjuvants (dimethyl sulfoxide [DMSO] at $20 \mu \mathrm{l} / \mathrm{ml}$ and Silwet L-77 at $20 \mu \mathrm{l} / \mathrm{ml}$ ) were evaluated on the ' $C a$. L. asiaticus'-infected periwinkle plants under greenhouse conditions. The factors were arranged in a split-plot design with three replicates. Adjuvant type (DMSO and Silwet L-77) was the whole-plot factor, while PS at four different application rates and blank control (without any spraying) were considered as the subplot treatments: (i) $1 \times$ (penicillin at $100 \mathrm{mg} / \mathrm{liter}$ and streptomycin at $10 \mathrm{mg} / \mathrm{liter}$ ), (ii) $5 \times$ (penicillin at $500 \mathrm{mg} / \mathrm{liter}$ and streptomycin at $50 \mathrm{mg} /$ liter), (iii) $10 \times$ (penicillin at $1 \mathrm{~g} / \mathrm{liter}$ and streptomycin at $100 \mathrm{mg} / \mathrm{liter}$ ), and (iv) $0 \times$ (water-treated control). Treatments were applied by spraying the ' $\mathrm{Ca}$. L. asiaticus'infected periwinkle plants using a ZEP 32-oz professional sprayer a total of three times at 1 -week intervals. Ten leaf samples per treatment were taken at 30,60, and 90 days after initial treatment (DAT). Data were analyzed as a generalized linear mixed model using the SAS procedure GLIMMIX. The whole-plot and subplot factors were treated as fixed effects, and replication and its interaction with the whole-plot factor as random effects. Differences among treatment levels were determined with the LINES option of the LSMEANS statement.

PS treatment on HLB-affected citrus. PS treatment components were compared separately and in combination. Fifteen of the 2-year-old grapefruit seedlings with typical HLB symptoms were treated by root soaking in solutions of penicillin $(\mathrm{P})$ at
$1.0 \mathrm{~g} /$ liter and streptomycin $(\mathrm{S})$ at $100 \mathrm{mg} / \mathrm{liter}$ alone and in combination. The trial was conducted three times at 1-week intervals. The treated seedlings were maintained in the USHRL greenhouse under standard conditions at $25 \pm 2{ }^{\circ} \mathrm{C}$ and watered as needed for commercial citrus nursery production. Five leaf samples were taken at 30,60, 90, and 180 DAT and DNA was isolated for qPCR analysis.

Six HLB-affected 6-year-old citrus trees (a unique hybrid, $10 \mathrm{c}-5-58$, which is an open-pollinated seedling from the combination of Lee mandarin $\times$ Orlando tangelo) at the USHRL farm, $10 \mathrm{~cm}$ in diameter, were injected with $100 \mathrm{ml}$ of each of the PS treatments (PS-5: $5 \mathrm{~g}$ of $\mathrm{P}+0.5 \mathrm{~g}$ of S per tree; PS-10: $10 \mathrm{~g}$ of $\mathrm{P}+1 \mathrm{~g}$ of $\mathrm{S}$ per tree; and PS-0: water as control) using an AvoJect syringe injector (a catheter-tipped 60-ml syringe; Aongatete Coolstores Ltd., NZ) in June 2009. The tapered tip was firmly fitted into a 19/64-in $(7.5-\mathrm{mm})$ diameter hole, $\approx 3 \mathrm{~cm}$ deep, drilled into the tree. Treatments were repeated a total of three times once every 2 months ( 8 June, 10 August, and 6 October 2009). Before treatment, $>30$ leaf samples per tree were taken from three positions around the canopy of the treated trees for qPCR assay at 2-month intervals in the first 6 months, and then taken at 10 and 14 months from initial treatments.

Genomic DNA extraction and qPCR analysis. Each leaf was rinsed three times with sterile water. Midribs were separated from the leaf samples and cut into pieces of 1.0 to $2.0 \mathrm{~mm}$. DNA was extracted from $0.1 \mathrm{~g}$ of tissue (fresh weight) of leaf midribs using Qiagen's DNeasy Plant Mini Kit (Qiagen, Valencia, CA) according to the manufacturer's protocol. qPCR was performed with primers and probes (HLBas, HLBr, and HLBp) for the ' $\mathrm{Ca}$. L. asiaticus' bacterium (27) using ABI PRISM 7500 sequence detection system (Applied Biosystems, Foster City, CA) in a 20- $\mu$ l reaction volume consisting of the following reagents: $300 \mathrm{nM}$ (each) target primer (HLBas and HLBr), $150 \mathrm{nM}$ target probe (HLBp), and 1× TaqMan qPCR Mix (Applied Biosystems). The amplification protocol was $95^{\circ} \mathrm{C}$ for $20 \mathrm{~s}$ followed by 40 cycles at $95^{\circ} \mathrm{C}$ for $3 \mathrm{~s}$ and $60^{\circ} \mathrm{C}$ for $30 \mathrm{~s}$. All reactions were performed in triplicate and each run contained one negative (DNA from healthy plant) and one positive (DNA from ' $\mathrm{Ca}$. L. asiaticus'-infected plant) control. Data were analyzed using the ABI 7500 Fast RealTime PCR System with SDS software. The resulting cycle threshold $(\mathrm{Ct})$ values were converted to the estimated bacterial titers using the grand universal regression equation $Y=13.82-$ $0.2866 X$, where $Y$ is the estimated log concentration of templates and $X$ is the qPCR Ct values, as described by Li et al. (28). As in the previous report (43), plants were considered to be PCR negative for ' $\mathrm{Ca}$. L. asiaticus' when the Ct values were $>36.0$, which is equivalent to the estimated bacterial titers of $<1,060$ cells/g of plant tissue.

\section{RESULTS}

Comparison of three treatments. Antibiotics (PS and Oxy) and a biocide agent (DBNPA) were tested for their antimicrobial activity against the ' $\mathrm{Ca}$. L. asiaticus' bacterium and evaluated for promoting regeneration and growth of ' $\mathrm{Ca}$. L. asiaticus'-infected periwinkle cuttings. Of the ' $\mathrm{Ca}$. L. asiaticus'-infected cuttings treated with PS, $>70 \%$ regenerated and grew but $<50 \%$ of the cuttings treated with Oxy and DBNPA successfully regenerated (Fig. 1). Variance analysis showed that there were significant effects of the chemical compounds $(P=0.000)$, treatment duration $(P=0.000)$, and their interactions $(P=0.000)$ on ' $C a$. L. asiaticus' bacterial titers in the fixed model. All plants regenerated from the ' $\mathrm{Ca}$. L. asiaticus'-infected cuttings treated with PS showed a marked reduction in ' $\mathrm{Ca}$. L. asiaticus' bacteria by 60 DAT and tested negative for the ' $C a$. L. asiaticus' bacterium via qPCR at 90 DAT, which was an estimated bacterial titer of $<500$ cells/g of plant tissue. When the ' $\mathrm{Ca}$. L. asiaticus'-infected cuttings were treated with DBNPA at concentration of $200 \mu \mathrm{l} / \mathrm{liter}$, 
' $C a$. L. asiaticus' bacterial titers were $>5 \times 10^{5}$ cells/g of plant tissue at 60 and 90 DAT, indicating limited suppression of the ' $C a$. L. asiaticus' bacterial population in the DBNPA-treated plants. However, ' $\mathrm{Ca}$. L. asiaticus' bacteria of the regenerated plants from the cuttings treated with Oxy were $\approx 8 \times 10^{5}$ cells $/ g$ of plant tissue at 60 DAT and decreased to $<500$ cells/g of plant tissue at 90 DAT (Fig. 2). The results indicated that the most effective chemical treatment was PS, with significant results seen at 60 DAT. Use of foliar sprays rather than root drenches on ' $\mathrm{Ca}$. L. asiaticus'-infected periwinkle plants showed that PS and Oxy treatments eliminated the ' $C a$. L. asiaticus'-bacterium, based on lower ' $C a$. L. asiaticus' bacterial titers and recovered growth, whereas DBNPA treatment of infected periwinkle did not fully eliminate the ' $C a$. L. asiaticus' bacterium, signified by higher 'Ca. L. asiaticus' bacterial titers after 90 DAT (Fig. 3).

Analysis of variance showed significant effects of the PS concentrations $(\mathrm{C}, P=0.000)$, DAT (A, $P=0.000)$, and their interactions $(\mathrm{A} \times \mathrm{C}, P=0.000)$ but no significant effects of adjuvants

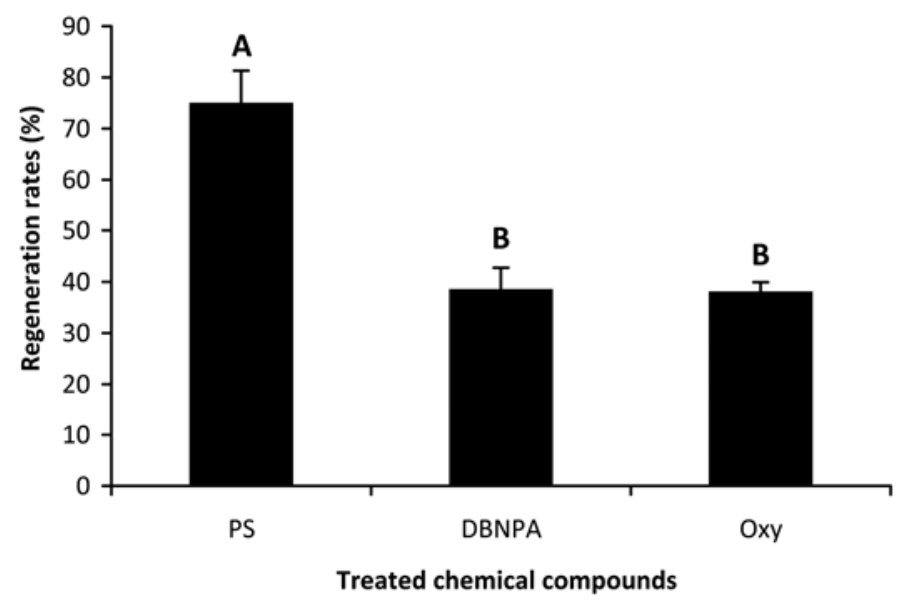

Fig. 1. Mean differences of the regeneration rates of 'Candidatus Liberibacter asiaticus'-infected periwinkle cuttings treated with a combination of penicillin and streptomycin (PS) (penicillin G potassium at $100 \mathrm{mg} / \mathrm{liter}$ and streptomycin at $10 \mathrm{mg} / \mathrm{liter}$ ), oxytetracycline (Oxy at $100 \mathrm{mg} / \mathrm{liter}$ ), and 2,2-dibromo3-nitrilopropionamide (DBNPA at $200 \mu \mathrm{l} /$ liter). Different capital letters (A and B) on the bar indicate that regeneration rates are significantly different $(P<$ $0.01)$.
$(\mathrm{B}, P=0.420)$ and their interactions with PS concentrations and DAT $(\mathrm{B} \times \mathrm{C}, P=0.121 ; \mathrm{A} \times \mathrm{B}, P=0.823 ; \mathrm{A} \times \mathrm{B} \times \mathrm{C}, P=0.164)$. DMSO and Silwet L-7 had no significantly different effects as adjuvants in the PS treatment (Supplemental Fig. 1). The ' $\mathrm{Ca}$. L. asiaticus' bacterial titers in all of the PS treatments, regardless of concentration, were 1,000-fold lower than those in the water and blank controls. This indicates that PS at the concentrations of $1 \times$, $5 \times$, and $10 \times$ significantly reduced or suppressed ' $\mathrm{Ca}$. L. asiaticus' bacterium in the ' $\mathrm{Ca}$. L. asiaticus'-infected periwinkles (Fig. 4).

HLB-affected citrus treated by root soaking with PS. The antibiotic combination PS effectively eliminated the ' $C a$. L. asiaticus' bacterium in ' $\mathrm{Ca}$. L. asiaticus'-infected citrus and provided a therapeutically effective level of control for 6 months, in contrast to treatments of $\mathrm{P}$ or $\mathrm{S}$ alone (Fig. 5). ' $\mathrm{Ca}$. L. asiaticus' bacteria at 30 DAT for PS (36,733 cells/g of plant tissues) was significantly lower than those individual treatments alone (282,180 cells for $\mathrm{P}$ and 500,766 cells for $\mathrm{S})$. P or S alone also suppressed the ' $\mathrm{Ca}$. L. asiaticus' bacterial population, as indicated by the lower ' $\mathrm{Ca}$. L. asiaticus' bacterial titers at 90 DAT, but the ' $C a$. L. asiaticus' bacterial titers returned to a relatively high population at 180 DAT (Fig. 5). The results indicated that PS enhanced the overall effectiveness of $\mathrm{P}$ and $\mathrm{S}$, demonstrating a synergetic and greater prolonged activity.

HLB-affected citrus treated with PS via injections. When HLB-affected citrus trees in the field of the USHRL farm at Fort Pierce were injected with different dosages of the PS (PS-0: water; PS-5: $5 \mathrm{~g}$ of $\mathrm{P}+0.5 \mathrm{~g}$ of $\mathrm{S}$ in $100 \mathrm{ml}$ of water/tree; and PS-10: $10 \mathrm{~g}$ of $\mathrm{P}+1 \mathrm{~g}$ of $\mathrm{S}$ in $100 \mathrm{ml}$ of water/tree), the estimated ' $C a$. L. asiaticus' bacterial titers decreased from 1,080,349 cells/g of plant tissue (prior to treatment) to 78,346 cells/g of plant tissue ( 2 months after initial treatment with PS-5). This is an $\approx 13$-fold reduction in the ' $\mathrm{Ca}$. L. asiaticus' bacterial titers in the treated citrus plants. The ' $C a$. L. asiaticus' bacterial titers tested in October 2009 were reduced to $<100$ cells/g of plant tissue (undetectable in qPCR), indicating the elimination or suppression of the ' $C a$. L. asiaticus' bacterium in the PS-treated plants. The ' $C a$. L. asiaticus' bacterial titers in the PS-5-treated citrus kept at $<1,000$ cells/g of plant tissue until 14 months after the PS treatments (Fig. 6). Similar results were observed when PS was applied at PS-10, except that it had phytotoxic effects on citrus (Supplemental Fig. 2 ). In contrast, the ' $C a$. L. asiaticus' bacterial titers from the water control treated plants remained $\approx 2 \times 10^{6}$ throughout the experiment (Fig. 6).

\section{DAT $\square 60$ DAT $\square 90$ DAT}

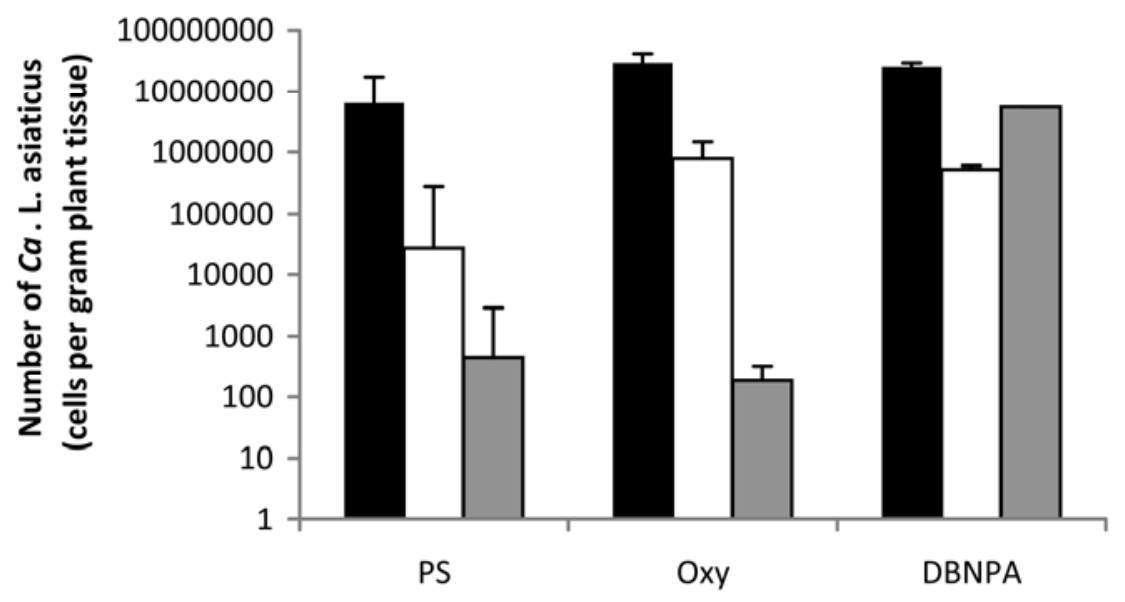

Treated chemical compounds

Fig. 2. Initial 'Candidatus Liberibacter asiaticus' bacterial titers (cells per gram of plant tissue) of ' $C a$. L. asiaticus'-infected periwinkle cuttings at 0 days after treatment (DAT) and variations of ' $\mathrm{Ca}$. L. asiaticus' bacterial titers (cells per gram of plant tissue) at 60 and 90 DAT in the regenerated plants treated by root drench with a combination of penicillin and streptomycin (PS) (penicillin at $100 \mathrm{mg} / \mathrm{liter}$ and streptomycin at $10 \mathrm{mg} / \mathrm{liter}$ ), oxytetracycline (Oxy at $100 \mathrm{mg} / \mathrm{liter}$ ), and 2,2-dibromo-3-nitrilopropionamide (DBNPA at $200 \mu 1 /$ liter). 


\section{DISCUSSION}

Citrus fruit is produced in 140 countries worldwide. Currently, most of the citrus-producing countries, including the top three producers (China, Brazil, and the United States), are suffering from HLB, the most devastating disease of citrus. HLB is difficult to manage, and maintaining production of citrus has proven to be difficult and expensive in areas where HLB is widespread. HLB has not been eradicated from any region where infection has been reported $(19,32)$. The first step in the successful management of HLB is the production of clean nursery stock because there is little chance of developing a productive tree when the tree is already infected at planting (20). With no established curative treatments or effective biological control, disease prevention has been the only way to fight against citrus HLB. A three-pronged approach to combat HLB was put forward after its occurrence in China: (i) to eliminate the ' $C a$. Liberibacter' inoculum by removal of symptomatic trees, (ii) to keep psyllid vector populations as low as possible by insecticide treatments, and (iii) to produce uninfected citrus trees in "closed", insect-proof nurseries for new orchards as well as for replacements of removed symptomatic trees. The same three measures are currently recommended in Florida (10). In our previous reports, we optimized a regeneration test system using ' $C a$. L. asiaticus'-infected periwinkle cuttings to screen antimicrobial compounds, and found that penicillin was effective in eliminating or suppressing the ' $\mathrm{Ca}$. L. asiaticus' bacteria (43). In this study, the combination of penicillin $\mathrm{G}$ and streptomycin had higher antimicrobial activities against the ' $\mathrm{Ca}$. L. asiaticus' bacterium than did the individual components alone or another tested antibiotic (Oxy) or the biocide agent DBNPA.

Penicillin G potassium, one of the bactericidal antibiotics, has activity against gram-positive and gram-negative aerobic and anaerobic bacteria by inhibiting bacterial cell-wall synthesis (15). We previously reported that penicillin $G$ sodium suppresses the HLB bacterium in ' $C a$. L. asiaticus'-infected periwinkle (43). Applications of antibiotics, such as water-soluble penicillin $G$ salts, as fertilizer components or as additives in irrigation water

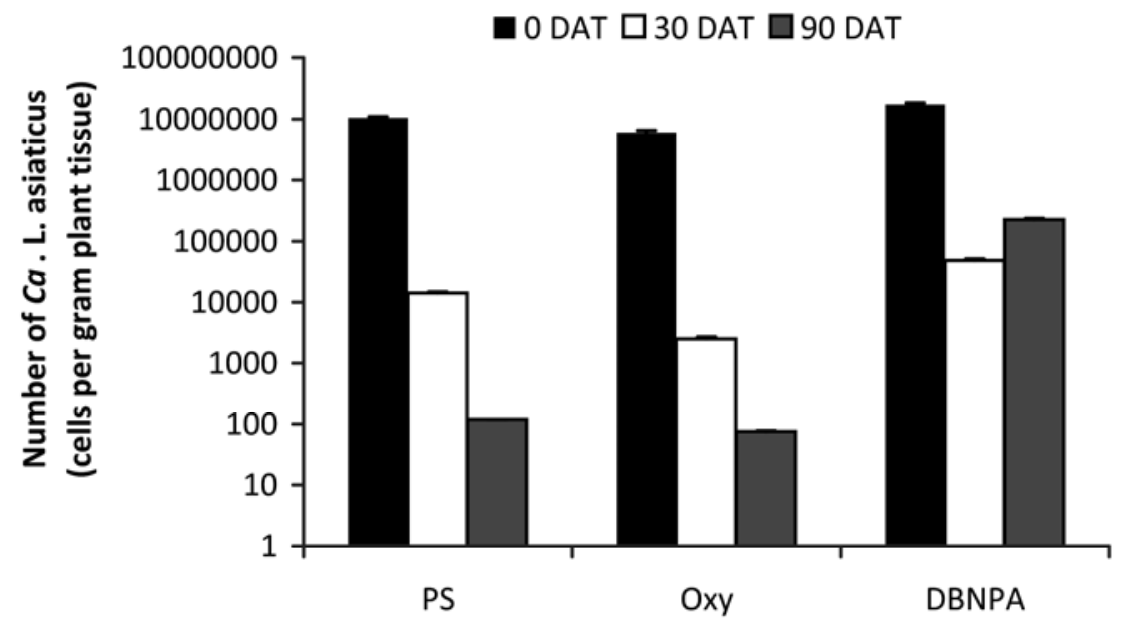

Treated chemical compounds

Fig. 3. 'Candidatus Liberibacter asiaticus' bacterial titers (cells per gram of plant tissue) at 0 (pretreatment), 30 , and 90 days after treatment (DAT) of 'Ca. L. asiaticus'-infected periwinkle plants treated by folial spraying with a combination of penicillin and streptomycin (PS) (penicillin at $100 \mathrm{mg} / \mathrm{liter}$ and streptomycin at $10 \mathrm{mg} /$ liter), oxytetracycline (Oxy at $100 \mathrm{mg} /$ liter), and2,2-dibromo-3-nitrilopropionamide (DBNPA at $200 \mu \mathrm{l} /$ liter).

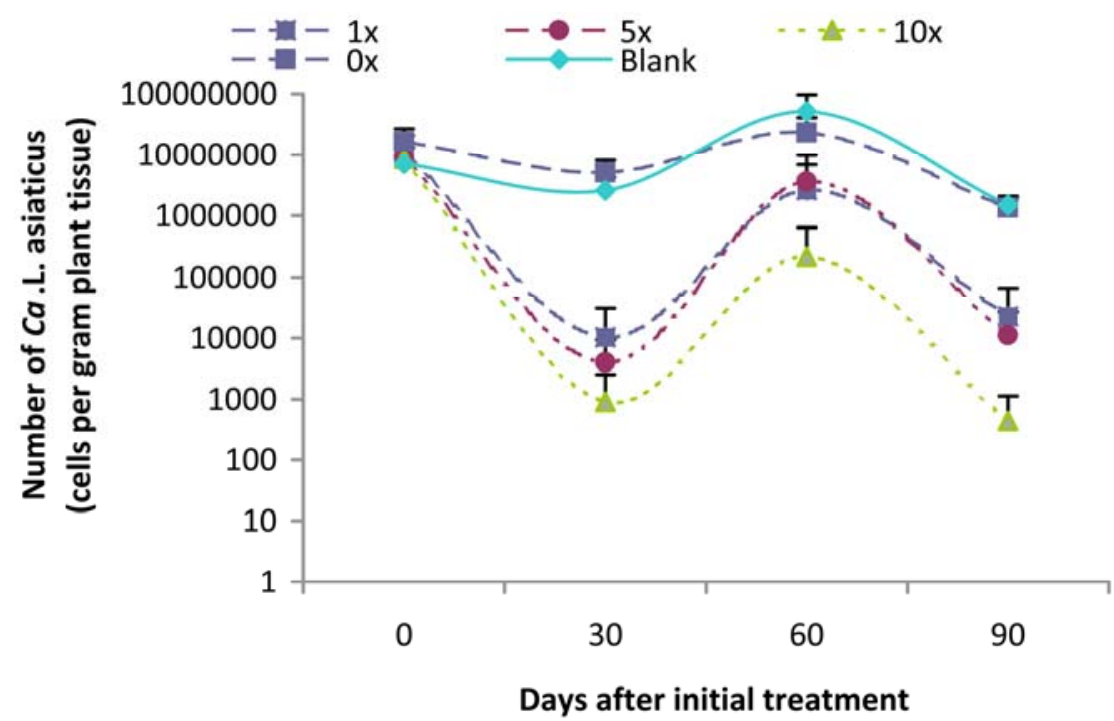

Fig. 4. 'Candidatus Liberibacter asiaticus' bacterial titers (cells per gram of plant tissue) in the ' $\mathrm{Ca}$. L. asiaticus'-infected periwinkle plants by foliar spraying with a combination of penicillin and streptomycin (PS) at concentrations of $0 \times$ (water as control), $1 \times$ (penicillin at $0.1 \mathrm{~g} / \mathrm{liter}$ and streptomycin at $10 \mathrm{mg} / \mathrm{liter}$ ), $5 \times$ (penicillin at $0.5 \mathrm{~g} /$ liter and streptomycin at $50 \mathrm{mg} /$ liter), and $10 \times$ (penicillin at $1.0 \mathrm{~g} /$ liter and streptomycin at $100 \mathrm{mg} / \mathrm{liter}$ ). Without any treatment was set up as the blank control (Blank). 
were patented for increasing the size or vigor of plants within a given period (U.S. Patent US2749230) or for reducing the time required for the sugarcane to reach normal maturity (U.S. Patent US3897239). Penicillin G potassium is taken up rapidly by plants, and was relatively nonphytotoxic in an earlier study (9). Streptomycin is an aminoglycoside antibiotic. It was first registered as a pesticide in 1955 for use in controlling bacterial pathogens of certain agricultural and nonagricultural crops (Streptomycin, Technical Evaluation Report, January 27 2006, compiled by ICF consulting for the United States Department of Agriculture National Organic Program). The primary mechanism of streptomycin action is binding irreversibly to the bacterial $30 \mathrm{~S}$ ribosome, changing its shape, and inhibiting protein synthesis by causing the misreading of mRNA (29).

In order to decrease the selection for antibiotic-resistant bacteria by exposure to penicillin and to avoid the side effects caused by streptomycin $(12,30)$, we combined penicillin and streptomycin in a cocktail application, which had an apparent synergetic effect and permitted a significant dosage reduction of streptomycin. The new combination enhanced activities against the ' $C a$. L. asiaticus' bacterium and remained at a therapeutically effective level for 6 months compared with the application of penicillin or streptomycin alone (Fig. 5). The effective application rates of PS ranged from penicillin at $0.1 \mathrm{~g} /$ liter and streptomycin at $10 \mathrm{mg} / \mathrm{liter}$ to penicillin at $1.0 \mathrm{~g} /$ liter and streptomycin at $100 \mathrm{mg} / \mathrm{liter}$ by root soaking and foliar spraying of ' $\mathrm{Ca}$. L. asiaticus'-infected periwinkle. A $>10$-fold increase in application rates of PS was required to treat the HLB-affected citrus by root-soaking in the greenhouse or by trunk-injection in the field. At PS-10 treatment, the PS phytotoxicity to citrus became apparent at the application rate of $100 \mathrm{ml}$ per injection, which was likely induced by the streptomycin component $(22,24)$. The greatest concern of those opposed to antibiotic use on plants is that spraying antibiotics in the open environment and over large expanses of land might increase the emergence of antibiotic-resistant bacteria. Some researchers found that streptomycin and tetracycline resistance genes were often carried on the same large plasmid in orchard bacteria but, when the plasmid was transformed into Escherichia coli, the new host was only resistant to tetracycline and not to streptomycin or the other antibiotics $(13,34)$.

Curative effects of the new combination PS have been demonstrated on the ' $C a$. L. asiaticus'-infected periwinkle by foliar

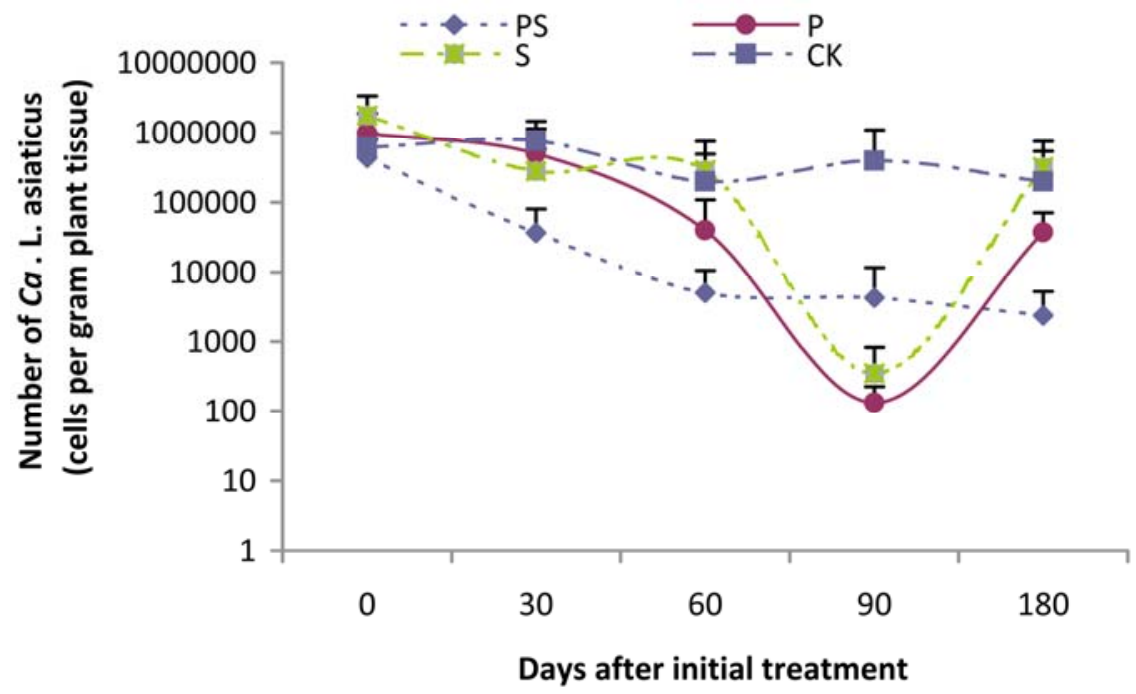

Fig. 5. Variations of 'Candidatus Liberibacter asiaticus' bacterial titers (cells per gram of plant tissue) in citrus Huanglongbing-affected citrus seedlings soaked with a combination of penicillin G and streptomycin (PS) or individual antibiotics alone: PS (penicillin $\mathrm{G} \mathrm{at} 1.0 \mathrm{~g} / \mathrm{liter}$ and streptomycin at $100 \mathrm{mg} / \mathrm{liter}$ ), $\mathrm{P}$ (penicillin $\mathrm{G}$ at $1.0 \mathrm{~g} /$ liter), $\mathrm{S}$ (streptomycin $100 \mathrm{mg} / \mathrm{liter}$ ), and CK (water control).

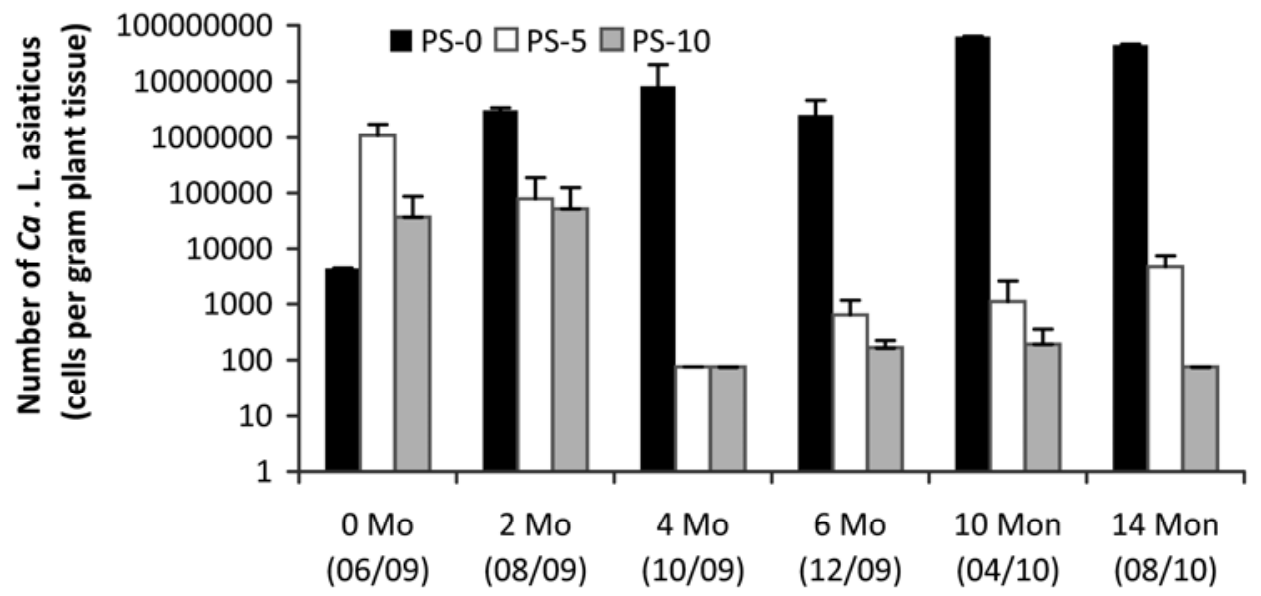

\section{Months after initial treatment}

Fig. 6. 'Candidatus Liberibacter asiaticus' bacterial titers (cells per gram of plant tissue) of the citrus Huanglongbing-affected citrus plants in the field treated with a combination of penicillin and streptomycin (PS) at different ratios: PS-5 (5 g of penicillin and $0.5 \mathrm{~g}$ of streptomycin in $100 \mathrm{ml}$ of solution) and PS-10 (10 g of penicillin and $1.0 \mathrm{~g}$ of streptomycin in $100 \mathrm{ml}$ of solution) by trunk injection. Water injection was used as a control (PS-0). 
spraying, on the HLB-affected citrus seedlings in the greenhouse by root soaking, and on the HLB-affected trees in the field by trunk injection. Tetracycline has been the only antibiotic to be approved for use through injection into the trunks of palm and elm trees to treat lethal yellow diseases caused by phytoplasmas (18). Although antibiotic application into a tree via injection is labor intensive, it decreases the antibiotic usage in the open environment and, thereby, reduces the potential for side effects to the environment. It would be of great value to cure orchards of citrus trees infected with HLB bacteria; however, considerable refinement and study of these treatments will be necessary prior to commercial application. In addition to phytotoxicity associated with Oxy treatments to cure HLB-infected citrus trees in South Africa, another reported problem was rapid reinfection of trees following antibiotic treatment $(14,40,41)$. Careful comparison of costs and benefits of injection treatments versus other control measures will be needed to determine whether antibiotic treatments can be profitably applied, and whether this merits expensive testing and deregulation for commercial use. Further evaluation of phytotoxicity of PS treatment levels and duration of HLB bacterial elimination is essential.

There are also other potential applications of such a curative procedure for rescuing the invaluable citrus plant material that have been infected by the HLB bacteria and ensuring that such plants are then HLB free and suitable for transfer to HLB-free areas. In addition, grower- or governmentally sponsored antibiotic application into home citrus may provide a way to protect these trees and, thereby, minimize likelihood of a pathogen reservoir. The effective chemical compounds demonstrated in this study may also be applied for the control of "zebra chip" disease of potato and tomato, which is associated with another close-related species of 'Ca. Liberibacter', 'Ca. L. solanacearum' (1).

\section{ACKNOWLEDGMENTS}

This work was supported by the Florida Citrus Advanced Technology Program award 161 and 162. We thank R. Stange and C. Latza for their excellent technical assistance in the research and L. Benyon and M. Hoffman for their critical review of the manuscript.

\section{LITERATURE CITED}

1. Abad, J. A., Bandla, M., French-Monar, R. D., Liefting, L. W., and Clover, G. R. G. 2009. First report of the detection of 'Candidatus Liberibacter' species in zebra chip disease-infected potato plants in the United States. Plant Dis. 93:108-109.

2. Abdullah, T. L., Shokrollah, H., Sijam, K., and Abdullah, S. N. A. 2009. Control of Huanglongbing (HLB) disease with reference to its occurrence in Malaysia. Afr. J. Biotechnol. 8:4007-4015.

3. Anne, M. V. 2002. Uses of antimicrobials in plant agriculture. Clin. Infect. Dis. 34 (Suppl. 3):S107-S110.

4. Aubert, B. 1990. Integrated activities for the control of Huanglongbinggreening and its vector Diaphorina citri Kuwayama in Asia. Pages 133144 in: Rehabilitation of Citrus Industry in the Asia Pacific Region. Proc. Asia-Pac. Int. Conf. Citri Culture. B. Aubert, S. Tontyaporn, and D. Buangsuwon, eds. Chiang Mai, Thailand.

5. Aubert, B. 1992. Citrus greening disease, a serious limiting factor for citrus culture in Asia and Africa. Proc. Int. Soc. Citricult. 2:817-820.

6. Aubert, B., Sabine, A., Geslin, P., and Picardi, L. 1984. Epidemiology of the greening disease in Reunion Island before and after the biological control of the African and Asian citrus psyllids. Proc. Int. Soc. Citricult. $1: 440-442$.

7. Bassanezi, R. B., Montesino, L. H., Amorim, L., Gasparoto, M. C. G., and Bergamin-Filho, A. 2008. Yield reduction caused by Huanglongbing in different sweet orange cultivars in São Paulo, Brazil. Pages 270-273 in: Proc. Int. Res. Conf. Huanglongbing, Orlando, FL.

8. Bassanezi, R. B., Montesino, L. H., and Stuchi, E. S. 2009. Effects of Huanglongbing on fruit quality of sweet orange cultivars in Brazil. Eur. J. Plant Pathol. 125:565-572.

9. Brian, P. W. 1957. Effects of antibiotics on plants. Annu. Rev. Plant Physiol. 8:413-426.

10. Brlansky, R. H., Dewdney, M. M., Rogers, M. E., and Chung, K. R. 2009. Huanglongbing (citrus greening). Florida Citrus Pest Management Guide.
Publication number PP-225. Institute of Food and Agricultural Sciences, University of Florida, Gainesville. Online: http://edis.ifas.ufl.edu/CG086.

11. Catling, H. D., and Atkinson, P. R. 1974. Spread of greening by Trioza erytreae (Del Guercio) in Swaziland. Pages 33-39 in: Proc. 6th Conf. Int. Organ. Citrus Virol. L. G. Weathers and M. Cohen, eds. IOCV, Div. Agric. Sci. Univ. Calif. Riverside.

12. Chadwick, D. J., and Goode, J. 1997. Antibiotic Resistance: Origins, Evolution, Selection, and Spread. Ciba Foundation Symposium 207. John Wiley and Sons, New York.

13. Chiou, C. S., and Jones, A. L. 1995. Molecular analysis of high-level streptomycin resistance in Erwinia amylovora. Phytopathology 85:324328.

14. Chiu, R. J., Tsai, M. Y., and Huang, C. H. 1979. Distribution of retention of tetracycline in healthy and likubin infected citrus trees following trunk transfusion. Pages 43-152 in: Proc. ROC-USA Coop. Sci. Semin. Mycoplasma Dis. Plants. National Science Council for Symposium Service, Taipei, Taiwan.

15. Davies, T. A., Page, M. G., Shang, W., Andrew, T., Kania, M., and Bush, K. 2007. Binding of ceftobiprole and comparators to the penicillinbinding proteins of Escherichia coli, Pseudomonas aeruginosa, Staphylococcus aureus, and Streptococcus pneumoniae. Antimicrobiol. Agents Chemother. 51:2621-2624.

16. FAO. 2003. Food and fertilizer technology centre for the Asian and pacific region, citrus greening and virus diseases of citrus, 2003-06-01. http://www.agnet.org/library/ac/2002d/.

17. Gatineau, F., Loc, H. T., Tuyen, N. D., Tuan, T. M., Hien, N. T. D., and Truc, N. T. N. 2006. Effects of two insecticide practices on population dynamics of Diaphorina citri and Huanglongbing incidence in South Vietnam. Page 110 in: Proc. Huanglongbing Greening Int. Workshop, Ribeirão Preto, Brazil.

18. Goodman, R. N. 1959. The influence of antibiotics on plants and plant disease control. Pages 322-448 in: Antibiotics: Their Chemistry and NonMedical Uses. H. S. Goldberg, ed. D. van Nostrand and Company, Inc., Princeton, NJ.

19. Gottwald, T. R. 2010. Current epidemiological understanding of citrus Huanglongbing. Annu. Rev. Phytopathol. 48:119-139.

20. Gottwald, T. R., da Graca, J. V., and Bassanezi, R. B. 2007. Citrus Huanglongbing: the pathogen and its impact. Online. Plant Health Progress doi: 10.1094/PHP-2007-0906-01.

21. Graça, J., and Korsten, L. 2004. Citrus Huanglongbing: review, present status and future strategies. Pages 229-245 in: Diseases of Fruits and Vegetables. Vol. I, Diagnosis and Management. SAMH Naqui, Kluwer Academic Press, Dordrecht.

22. Gray, R. A. 1955. Inhibition of root growth by streptomycin and reversal of the inhibition by manganese. Am. J. Bot. 42:327-331.

23. Halbert, S. E., and Manjunath, K. L. 2004. Asian citrus psyllids (Sternorrhyncha: Psyllidae) and greening disease of citrus: A literature review and assessment of risk in Florida. Fla. Entomol. 87:330-353.

24. John, L. N., Jones, A. L., and Herb, S. A. 2003. Fire blight management in the twenty-first century: Using new technologies that enhance host resistance in apple. Plant Dis. 87:756-765.

25. Leonard, G. C., and Stephen, O. D. 2007. Natural products that have been used commercially as crop protection agents. Pest Manage. Sci. 63:524554.

26. Levy, S. B. 1998. The challenge of antibiotic resistance. Sci. Am. 278:4653.

27. Li, W. B., Hartung, J. S., and Levy, L. 2006. Quantitative real-time PCR for detection and identification of 'Candidatus Liberibacter' species associated with citrus Huanglongbing. J. Microbiol. Methods 66:104-115.

28. Li, W. B., Hartung, J. S., and Levy, L. 2008. Optimized quantification of unculturable 'Candidatus Liberibacter spp.' in host plants using real-time PCR. Plant Dis. 92:854-861.

29. Luzzatto, L., Apirion, D., and Schlessinger, D. 1968. Mechanism of action of streptomycin in E. coli: interruption of the ribosome cycle at the initiation of protein synthesis. PNAS 60:873-880.

30. McManus, P. S., and Jones, A. L. 1994. Epidemiology and genetic analysis of streptomycin-resistant Erwinia amylovora from Michigan and evaluation of oxytetracycline for control. Phytopathology 84:627-633.

31. McManus, P. S., Stockwell, V. O., Sundin, G. W., and Jones, A. L. 2002. Antibiotic use in plant agriculture. Annu. Rev. Phytopathol. 40:443-465.

32. NRC 2010. Strategic Planning for the Florida Citrus Industry: Addressing Citrus Greening. National Academies Press, Washington, D.C.

33. Roistacher, C. N. 1996. The economics of living with citrus diseases: Huanglongbing (greening) in Thailand. Pages 279-285 in: Proc. 13th Conf. Int. Organ. Citrus Virol. P. Moreno, J. V. da Graça, and R. K. Yokomi, eds. IOCV, Riverside, CA.

34. Schroth, M. N., Thompson, S. V., and Moller, W. J. 1979. Streptomycin resistance in Erwinia amylovora. Phytopathology 69:565-568.

35. Schwarz, R. E., and van Vuuren, S. P. 1970. Decreases in fruit greening of sweet orange by trunk injections with tetracycline. Plant Dis. Rep. 
55:747-750.

36. Shelton, A. M., and Badenes, F. R. 2006. Concepts and applications of trap cropping in pest management. Annu. Rev. Entomol. 51:285-308.

37. Su, H. J., and Chang, S. C. 1974. Electron microscopical study on the heat and tetracycline response, and ultra-structure of the pathogen complex causing citrus likubin disease. Pages 628-629 in: Proc. 8th Int. Congr. Electron Microscopy, Vol. 2., Canberra, Australia.

38. Supriyanto, A., and Whittle, A. M. 1991. Citrus rehabilitation in Indonesia. Pages 409-413 in: Proc. 11th Conf. IOCV. IOCV. Riverside, CA.

39. Sutton, B., Duan, Y. P., Halbert, S., Sun, X. A., Schubert, T., and Dixon, W. 2005. Detection and identification of citrus Huanglongbing (greening) in Florida, USA. 2005. Page 59 in: Proc. Second Int. Citrus Canker Huanglongbing Res. Workshop, Orlando, FL.
40. Van Vuuren, S. P. 1977. The determination of optimal concentration and $\mathrm{pH}$ of tetracycline hydrochloride for trunk injection of greening-infected citrus trees. Phytophylactica 9:77-81.

41. Van Vuuren, S. P., Moll, J. N., and da Graca, J. V. 1977. Preliminary report on extended treatment of citrus greening with tetracycline hydrochloride by trunk injection. Plant Dis. Rep. 61:358-359.

42. Waksman, S. A. 1996. Antibiotics today. Bull. N.Y. Acad. Med. 42:623632.

43. Zhang, M. Q, Duan, Y. P., Zhou, L. J., Turechek, W. W., Stover, E., and Powell, C. A. 2010. Screening molecules for control of citrus Huanglongbing using an optimized regeneration system for 'Candidatus Liberibacter asiaticus'-infected periwinkle (Catharanthus roseus) cuttings. Phytopathology 100:239-245. 